\title{
BIOETHICS AND HUMAN CLONING
}

\section{Željko Kaluđerović ${ }^{1}$ \\ Sonja Antonić}

Faculty of Philosophy, Novi Sad

Received: 02.06.2011

UDC: $179: 577.214$

Accepted: 10.10.2011

\begin{abstract}
S
In this paper the authors analyze the process of negotiating and beginning of the United Nations Declaration on Human Cloning as well as the paragraphs of the very Declaration. The negotiation was originally conceived as a clear bioethical debate that should have led to a general agreement to ban human cloning. However, more often it had been discussed about human rights, cultural, civil and religious differences between people and about priorities in case of eventual conflicts between different value systems. In the end, a non-binding Declaration on Human Cloning had been adopted, full of numerous compromises and ambiguous formulations, that relativized the original intention of proposer states. According to authors, it would have been better if bioethical discussion and eventual regulations on cloning mentioned in the following text had been left over to certain professional bodies, and only after the public had been fully informed about it should relevant supranational organizations have taken that into consideration.
\end{abstract}

Key words: bioethics, human cloning, reproductively, therapeutically, UN Declaration

The Declaration on Human Cloning (No. 59/280) was adopted on the 82 OUN plenar session held on 8 March 2005. This declaration represents the crown of efforts taken since 2001 by France and Germany to adopt a convention against reproductive human cloning. Instead of unanimous consent from the international community, negotiations followed that lasted 4 years and showed the diversity of the world in which we live.

1 Correspodence to:

Željko Kaluđerović PhD, Faculty of Philosophy, Novi Sad

Dr Zorana Đinđića 2, 21000 Novi Sad, Serbia

Phone: +38121459279

E-mail: zeljko.kaludjerovic@gmail.com

2 The word »cloning « comes from Greek masculine noun $\kappa \lambda \omega \dot{\omega}$, translated as »stem« or »twig«. It stood for »offspring « in New Testament. To find out more on cloning dilemmas see text Antonić (2009, p. 173-183).
The negotiations were originally conceived in a completely different way, as a clear bioethical debate that should have led to general agreement to ban human cloning. ${ }^{2}$ However, more often it had been discussed about human rights, cultural, civil and religious differences between people, their interactions and priorities in case of eventual conflicts between different value systems. 
Neither the Declaration nor the negotiations gave any answers to these difficult questions, but they did allow superficial insight into problems. They showed that international legislation does not possess the knowledge to deal with problems when there is no professional argumentation but political and other differences in the middle of discussion.

The adopted declaration represents the negotiation result, and it includes, both in bioethical and in scientific sense, ambiguous formulations that can be interpreted different ways. If one reads the declaration carefully, it has an unexpected result, since it does not ban cloning ${ }^{3}$ explicitly, not even reproductive cloning. However, the significance of years of negotiations can be hardly limited to the very Declaration. Of equal, or maybe even of more importance, is to make the public, wider scientific community and state governments aware of different bioethical questions as well as to urge the authorities and scientific associations for establishment of a suitable legislation and giving references for the explorations of stem cells.

Taken into account the fact that, at the given moment, only a small number of scientists and institutions dispose of required technical education, Germany and France held that reproductive cloning ${ }^{4}$ of 3 One of the definitions of cloning and research of stem cells says: »Cloning of an organism commonly involves a technique called somatic cell nuclear transfer, where the nucleus of an egg cell (containing its genetic material) is removed and replaced with the nucleus of a somatic cell taken from the body of an adult. If the reconstructed egg cell is then stimulated successfully to divide, it may develop to the pre-implantation blastocyst stage. In reproductive cloning, the cloned blastocyst is then implanted in the uterus of a female and allowed to continue its development until birth. However, in cloning for research or therapeutic purposes, instead of being implanted in the uterus the cloned blastocyst is converted into a tissue culture to make a stem cell line for research or clinical applications.« (InterAcademy Panel on International Issues, 2003).

4 There is a general, if not absolute agreement, in the international community on the view that reproductive people can affect the whole mankind, which is why they demanded wide action. They demanded global instruments that would produce relevant normative acts and so their wish was to entrust the task to the UN General Assembly instead of to some of the specialized agencies such as the World Health Organization (WHO) or UNESCO. It was expected that, due to the stance of the European Union ${ }^{5}$ and UNESCO Declaration, ${ }^{6}$ the negotiations would be of short duration and that the stances would be quickly and easily formulated into a clear and binding convention.

Taken into account the novelty in consideration of the aforementioned problems and unfamiliarity with medical and technical terminology, negotiations of 2002 started by informing scientists and philosophers on basic mechanisms of cloning process, as well as on the ethical implications of the aforementioned process. ${ }^{7}$

cloning, for the purpose of creating new human beings, is a deeply unethical act. Arguments against reproductive cloning are of technical and medical nature such as weakening and undermining of the original idea of producing offspring and the concept of family, unclear relationship between the cloned baby and its »creator«, confusable personal identity and possible disturbance of psychologic development of the cloned baby, eugenic questions, promoting creation of babies and their »enhancement«, belief that reproductive cloning contradicts human dignity. Key argument that goes in favour of reproductive cloning is the increase of favourable reproduction possibilities. By helping infertile people with cloning one promotes their welfare, preserves their personal autonomy and satisfies their natural desire for producing offspring (Strong, 2008, pp. 130-136).

5 Additional Protocol of the Council of Europe, http:// conventions.coe.int/Treaty/Commun/ListeTraites. asp? $\mathrm{CM}=8 \& \mathrm{CL}=\mathrm{ENG}$.

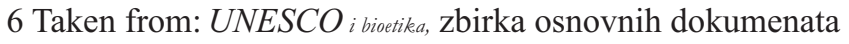
(Center for Ethics and Law in Biomedicine, 2008, p. 6).

7 Habermas (2002) tends to claim that ethics is the best approach to deal with the problem of cloning. As long as cloning remains the consequence of human actions, it also remains a subject to human responsibility, therefore to ethics as well. 
At first, the problem was aimed only at those states involved in genetic research or those who had capabilities to do it. Some of them thought that the French-German initiative was acceptable, since it tended to ban human cloning, on which they all agreed, leaving research of stem cells and $»$ therapeutic cloning $\aleph^{8}$ by side.

Other states didn't think that there's a difference between the two types of cloning, taken into account that both include the manipulation of a human embryo.

The discussion on cloning had quickly turned into the discussion on when does human life begin and on dilemmas regarding abortion, the topic on which there is no agreement in international community.

The United Nations Declaration on Human Cloning $^{9}$ is short and meaningful and it consists of eight preambular and six operative paragraphs. The language of the Declaration is common and each of its paragraphs has gradual transitions, careful qualifications and key terms implications. This shows that one tried to reach balance between dissenting and hardly compatible definitions of human life, presented by opposing sides. As a result of that the Declaration conveys the consensus neither on human cloning nor on the beginning of human life, and it does not define none of the aforementioned concepts. As stated in the 8 Some scientists call therapeutic cloning »cloning for research purposes «, or »research cloning «. The intention is to avoid the use of the term »therapeutic«, which, in their view, can have positive connotations, but since they are not proven at this moment, it is suggested to use a more neutral syntagm. Be that as it may, it is expected that therapeutic cloning will help in the treatment of many serious and chronic diseases, of which most often mentioned are Parkinson's disease, Alzheimer's disease or diabetes. The biggest ethical question regarding therapeutic cloning is concerned with debates on moral status of the embryo.

9 The full name is »The United Nations Declaration on Human Cloning«; for its English version see: http://www. unescobkk.org/fileadmin/user_upload/shs/BEfiles/chapterE. eng/E8.2E.pdf. introduction, the Declaration neither defines human cloning nor does it directly or unconditionally ban human cloning, including reproductive cloning.

One reference to reproductive cloning can be found in the second preambular paragraph, that states: »Recalling the Universal Declaration on the Human Genome and Human Rights adopted by the General Conference of the United Nations on 11 November 1997, and in particular article 11 thereof, which states that practices that are contrary to human dignity, ${ }^{10}$ such as the reproductive cloning of human beings, shall not be permitted «. Other paragraphs in the preambular part discuss the application of »life sciences«. This syntagm »life science« was a subject to objections coming from state delegations pleading for the Declaration on Human Cloning to be summarized and paraphrased into the Declaration on Human Cloning for reproduction purposes. In their view, the negotiation process was never directed at the debate on life sciences in general, adding it is not clear neither what does the mentioned concept include nor what does it stand for. ${ }^{11}$

In the preambular part of the Declaration life sciences are only mentioned in relation to the

10 The very concept of human dignity is not defined specifically. Representatives of the universal ban on all forms of cloning related this term to non-sexual production of human beings. The representative of Vatican tried to define dignity as an intrinsic value, common and equal for all human beings, no matter their social, intellectual or human condition. Human dignity was also often brought in connection with Kant's second formulation of categorical imperative (»Act in such a way that you treat humanity whether in your own person or in the person of any other, always at the same time as an end and never merely as a means to an end." Kant, 2004 , p. 74), i.e. with the fact that creation of children by means of cloning could lead to treatment of offspring as an object, i.e. as a material thing as is a house or car ( Putnam, in: Burley, ed., The genetic revolution and human rights, 1997, p. 1-13).

11 One footnote (No. 42) from Professor Šegota in his text «Nova definicija bioetike», In: A. Čović, Izazovi bioetike (2000, p. 22), closely defines »life sciences«. 
concern about »human dignity«, »fundamental freedoms of individuals« as well as »relief from suffering«, »health improvement both of individuals and of mankind in general« and »benefits for all«.

Therefore, no matter what life sciences actually signify, they should be understood in the context of terms with which they were brought in connection with, especially with the term »human dignity«. This is especially visible in the last eighth preambular paragraph which states that the General Assembly »is convinced of the urgency of preventing the potential dangers of human cloning to »human dignity«. Words from this paragraph that can be interpreted different ways are »potential dangers« and »human dignity«. Meticulously stated formulations are also visible in the emphasis of the word potential that stands before danger, suggesting that the dangers human cloning can cause to human dignity can also be interpreted as potential, i.e. only as possible.

Two extremely important paragraphs of the second operative part of the Declaration, paragraphs »a« and $» b \ll$, were heating the discussions between the opposing sides till the very end of the negotiation process. Paragraph (a) declares: »Member states are called upon to adopt all measures necessary to protect adequately human life (put in italics by Ž.K.) in the application of life sciences«. This paragraph was supported by delegations who voted in favour of the general ban on cloning and it was strongly opposed by states supporting the ban on cloning only for reproduction purposes. Why this is so when cloning of people is not even mentioned in it? It refers to protection of human life in life sciences. The reason for opposing this paragraph lies within the fact that the phrase "protection of human life« can be widely interpreted, including the interpretation of the abortion ban.

The paragraph was also criticized because it mixes scientific definition of »human life« and determination of »human being «, which should be a subject to legal regulations.

During negotiations the adverb »adequately« was used to modify the verb »to protect«, thereby emphasizing that the phrase »adequate protection of human life« differs from eventual »full protection of human life«. State delegations supporting only ban on reproductive cloning, could not accept paragraph (a), not even with this subtle annex. In their view, therapeutic cloning includes and comprehends the human embryo, which, seen through scientific prism, can be defined as a »form of human life $\ll$, but not as a »human being«. These states simply could not agree with the formulation requiring the protection of all »forms of human life $\ll .^{12}$

Paragraph (b) is the only operative paragraph which bans human cloning, although it includes important alleviation of the original formulation. It declares: »Member states are called upon to prohibit all forms of human cloning inasmuch as (italics Ž.K.) they are incompatible with human dignity and the protection of human life«. This paragraph was also a subject to debate from states supporting only the ban on reproductive cloning. Although the phrase »all forms of human cloning« can be widely interpreted and it includes reproductive human cloning as well, it was alleviated and modified by the word »inasmuch as $\ll$. This expression was chosen in English because it could convey several meanings, which are »as«, »because« or »since« or in some other context »if« or »on condition that «, therefore allowing everybody to choose the interpretation that best suits them.

12 Belgium, the leader of the countries opposing this paragraph, demanded its deletion, i.e. annulment, but its suggestion was rejected in the Sixth committee (with 57 to 48, 42 abstentions). 
Namely, the version of translation, in which one grasps »inasmuch as« as »since« (»Member states are called are called upon to prohibit all forms of human cloning since they are incompatible with human dignity and the protection of human life.«), is a call for a total ban on human cloning.

Alternative translation, in which one interprets »inasmuch as« as »if« (»Member states are called upon to prohibit all forms of human cloning if they are incompatible with human dignity and the protection of human life.«), leaves the possibility open that there are forms of human cloning that can be »compatible« with the human dignity and protection of human life. ${ }^{13}$

Along with many restrictions and modifications paragraph (b) was unacceptable to many delegations, especially to the ones supporting only the ban on reproductive cloning. Their remarks were aimed at the fact that paragraph (b) does not explicitly ban human reproductive cloning and that it repeats phrases as "protection of human life«, which were already adequately explained in paragraph (a). For delegations supporting total ban on human cloning, paragraph (a) refers to the use of life science but does not explicitly mention human cloning and issues mentioned in paragraph (b). Belgium was the leader of states opposing paragraph (b) and suggested the modified version of this paragraph: "Member states are called upon to ban reproductive cloning of human beings. They are also called upon to ban all other forms of human cloning inasmuch as they are incompatible with human dignity«. This suggestion recognizes different forms of cloning based on the intention (reproductive or therapeutic), and bans reproductive cloning and other forms of cloning 13 The phrase "protection of human life« can also be understood in the aforementioned context modified by the adverb »adequately«. (therapeutic), inasmuch as they are not respecting human dignity. The suggestion was unacceptable to states supporting total ban on cloning probably due to its ambiguity and the fact that it does not mention human life. Therefore, it was rejected in the Sixth Committee.

The negotiations in the United Nations about the Declaration on Human Cloning showed that bioethical dilemmas and scientific discourse were relatively easily replaced with statements that are not formulated in regards to the interests of profession and human needs. They were heavily coloured by political, economic, cultural and religious characteristics of individual state groups or individual states. The effort to make the standard universal in order to deal with one, in scientific sense, sophisticated problem, led to significant differences and disagreements on scientific and technological development and priorities between 191 UN member states. Therefore, there was no non-binding declaration that could be adopted without numerous compromises and ambiguities, which significantly relativized the original intention of proposer states.

Finally, maybe it would have been better if the bioethical debate on the cloning issue and eventual regulations had been left over to experts and suitable professional bodies, ${ }^{14}$ and only after the public had been fully informed about it, should relevant supranational institutions have dealt with the problem.

14 The general director of UNESCO at the time Koichiro Matsuura also considers that scientists and bioethicians should play a leading role in discussions on cloning and main ethical questions stated in relation to cloning, which are of interest for the whole mankind. He adds that other subjects, such as public opinion, should play a significant role in the wide ethical debate on such an important question (UNESCO, 2005, preface, p. 5). 


\section{REFERENCES}

- Additional Protocol of the Council of Europe, http://conventions.coe.int/Treaty/Commun/ListeTraites. asp? $\mathrm{CM}=8 \& \mathrm{CL}=\mathrm{ENG}$.

- Antonić, S. (2009). Kloniranje kao etički problem [Cloning as an ethical problem], ARHE, Year VI, No. 12, Novi Sad, Serbia.

- Center for Ethics and Law in Biomedicine (2008). UNESCO and bioethics, Budapest: Author.

- Habermas, J. (2002). Postmetafizičko mišljenje [After metaphysical thinking]. Beograd, Serbia: Beogradski krug.

- InterAcademy Panel on International Issues, (2003). Statement on Human Cloning, Trieste, Italy.

- Kant,I.(2004).Zasnivanjemetafizikemorala[Establishing moral metaphysics], Beograd, Serbia: Dereta.

- Putnam, H., (1997). »Cloning People«, in: J. Burley, ed. The genetic revolution and human rights, Oxford: Oxford University Press.

- Strong, C. (2008). Cloning and adoption: a reply to Levy and Lotz Bioethics, 22(2).

- Šegota, I. (2000). Nova definicija bioetike [The new definition of bioethics], in: A. Čović, Izazovi bioetike [The Challenges of Bioethics], Zagreb, Croatia. Pergamena, Hrvatsko filozofsko društvo.

- Švajger, A.. Kloniranje: pojmovi, zablude, obmana i strah«; see: http://www.vms.hr/school/klon01.htm.

- The United Nations Declaration on Human Cloning.

- www.unescobkk.org/fileadmin/user_upload/shs/BEfiles/ chapterE.eng/E8.2E.pdf.

- UNESCO, (2005). Human Cloning Ethical Issues, Paris. 